\title{
APP-101-AM＼cjkstart尿路結石発生起点におけるオステオポンチンの結晶疑集メカニズム〜オステオポンチン ノックアウトマウスを用いた超微細構造観察〜
}

\author{
中日病院泌尿器科1), 名古屋市立大学大学院医学研究科腎・泌尿器科学分野2

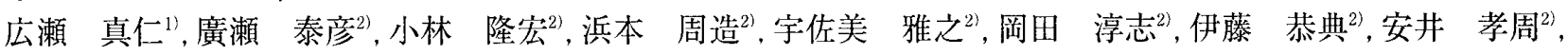 \\ 戸澤 啓一2), 郡 健二郎 ${ }^{2)}$
}

【目的】これまでの実験動物を用いた尿路結石研究は、結石ができあがった後の組織や、血液、尿を用いて検討をしていることが多い。し かし、あらたな尿路結石治療を考えるうえで、結石形成の起点を解明すること、特に結石マトリックスの主成分であるオステオポンチン (OPN)の発現様式を明らかにすることが重要である。今回私たちは、OPNノックアウトマウスを用いて、電子顕微鏡による詳細な形態学 的、免疫組織学的検討を行い、尿路結石形成初期に扔汀超微練構造の変化と OPN の作用について解明したので報告する。】方法】 8 週齢 C57BL $/ 6$ 雄マウスおよび、 OPN ノックアウトマウスヘグリオキシル酸 $100 \mathrm{mg} / \mathrm{kg}$ 老腹腔内単回投与した。投与直前、投与 $6 、 12 、 24$ 時間後 にそれぞれ愛護的に麻醉下にて腎臟を採取した。透過型電子顕微鏡 (TEM) により腎尿細管細胞の微細構造を観察し、OPNノックアウト マウスと、C57BL/6 マウスの尿細管細胞の変化について検討を行った。さらにC57BL/6 雄マウスの腎尿細管細胞における OPNの変化を 光学䫓微鏡、およびTEMを用いての免疫染色法にて形態的に観察した。また、グリオキシル酸 $100 \mathrm{mg} / \mathrm{kg}$ を 6 日間連日腹腔内投与し、C 57BL/6 雄マウスおよび、OPNノックアウトマウスの腎臟内に結石を作成し、形態の差について偏光顕微鏡で観察した。結果】投与 12 時間後には両群とも尿細管管肱内に細胞内小器官が徐々に出現しているが、結石形成は認めなかった。24時間後では C57BL/6 マウスの尿 細管管腔内には結晶核が出現したが、OPNノックアウトマウスでは細胞内小器官は尿細管管䏕内に多く存在するが、結晶は認めなかった。 OPN は 6 時間後には細胞内に出現し、12 時間後には尿細管の管胿内に出現した細胞内小器官とともにみられた。結晶核の出現している 24 時間後には結晶核の周辺に細泡内小器官とともに OPN が存在していた。偏光瀕微镜で結石を観察すると、C $57 \mathrm{BL} / 6$ マウスの結石形態は一 つ一つの結晶が大きくそれが集まり、結石を形成していた。PNノックアウトマウスでは結晶は一つ一つの結晶が小さく、小さな結晶が 寄り集まっているのみで、大きな結石になってはいなかった。考察]結石形成初期には、細胞の障害により細胞内小器官が尿細管の管腈内 へ出現し、管胿内で出現した小器官が結晶核を形成するという微細丵造の変化が起きると考えられた。また、OPN は尿細管の管腔内で細 胞内小器官を凝集させ、結晶核の形成を促進し、さらに大きな結晶を形成する作用“結石増大作用”を持つ可能性が示唆された。

\section{APP-102-AM＼cjkstart尿路結石症とメタボリックシンドロームの関連性についての基礎的検討}

\section{和歌山県立医科大学医学部泌尿器科学}

射場 昭典, 柑本 康夫, 佐々木 有見子, 新谷 寧世, 稲垣 武, 原 勲

【目的】肥満、糖尿病、高血圧といったメタボリックシンドロームに関連する疾患を有する患者に尿路結石の発生率が高いことが報告 されている。今回、我々は過食による内臟脂肪蓄積型肥満から高卜リグリセリド血症、2 型糖尿病、高血圧を引き起こし、ヒトのメ夕 ボリックシンドロームに類似した病態を呈する OLETF (Otsuka Long-Evans Tokushima Fatty) ラットと対照の LETO (Long-Evans Tokushima Otsuka) ラットを用いて、メタボリックシンドロームおよびその主たる病態であるインスリン抵抗性が尿路結石形成に及 ほす影響について検討した。対象と方法】実験 1:4 週龄・雄 OLETF およびLETOラット 10 匹ずつを通常食、自由飲水下に飼育し、 4 週毎に 24 週齢まで体重測定、血液検查、24 時間尿化学検査を行い、両群を比較することによりメタボリックシンドロームラットに おける結石形成リスクを評価した。実験 $2: 10$ 週龄・雄 OLETF ラットにインスリン抵抗性改善剤 pioglitazone 3 あるいは $10 \mathrm{mg} /$ $\mathrm{kg} / \mathrm{day}$ で 4 週間経口強制投与し、インスリン抵抗性の改善が尿中結石関連物質に及ぼす影響を検討した。結果]実験 1:OLETF ラッ トの体重は 4 週齢より、血清トリグリセリド值は 8 週齢より、血糖值および血清インスリン值は 12 週龄より LETOラットに比較して 有意に高かった。2 時間尿検查では、OLETFラットの尿 $\mathrm{pH}$ おるよ゙゙尿中クエン酸排泄量は経時的に低下傾向を示し、それぞれ 8 週齢、 12 週齢以降はLETO ラットに比較して有意に低かった。また、OLETF ラットの尿中尿酸排泄量およびカルシウム排泄量は経時的に 増加傾向を示し、それぞれ 4 週齢、20 週齢以降は LETO ラットに比較して有意に高かった。実験 2 ：尿 pH は pioglitazone の投与によ り濃度依存性に有意な上昇がみられた。一方、尿中クエン酸、尿酸、カルシウム、シュウ酸、マグネシウム排泄量に有意な変化はみら れなかった。結論]メタボリックシンドロームのモデルである OLETF ラットでは、体重増加、高トリグリセリド血症、高血糖、高イ ンスリン血症の出現とともに、尿 $\mathrm{pH}$ 抢よび尿中クエン酸排泄量の低下、尿中尿酸拉よびカルシウム排泄量の增加がみられ、尿路結石 の発症リスクが高くなることが示された。またインスリン抵抗性改善剤である pioglitazoneの投与により OLETFラットにおける尿 $\mathrm{pH}$ 低下に改善がみられた。このようにメタボリックシンドロームは尿中結石関連因子を変化させることにより結石形成を促進玄る と考えられることから、その本態である肥満/内臓脂肪蓄積を改善することによって結石形成が予防できる可能性が示唆される。 